\title{
CONTINUITY AND CHANGE IN JAVANESE LEGAL TRADITION : THE EVIDENCE OF THE JAYAPATTRA
}

\author{
Mason C. Hoadley
}

old Javanese epigraphy may be divided among several categories depending on the kind of information which individual inscriptions provide. By far the most common type of inscription found in Java is the prasasti, often called piagem, which is a royal charter proclaiming the grant of certain rights or privileges, usually associated with land or taxes, to favored groups or individuals. The prasasti usually begins or closes with the phrase "iti prasasti radja" ("this is the charter of the king"). A second type, the royal edicts and proclamations, generally begin with the word wruhe or $\bar{a} j \tilde{n} \bar{a}$, Sanskrit for "order, command." Other classes of inscriptions which can also be identified by content include surat ("letters of rescript"), suddhapattra (receipts for debt repayment), and jayapattra ("certificates of victory" awarded to the winners of lawsuits).

In each case the document was most likely promulgated originally on Zontar or some other perishable material and only later recopied on copper plates or stone tablets. ${ }^{2}$ The document represents the end product of an extensive executive or judicial procedure. In most cases, information explaining the reason for its promulgation is rarely provided by the document itself, though such information can occasionally be derived from the study of other materials. One specialized type of epigraphic document does contain within it the basic information concerning how and why it was promulgated. Borrowed from ancient Indian practice, the jayapattra typically includes a detailed description of the judicial process by which it

1. Examples of a prasasti, a piagem, a royal edict, a surat and a jayapattra can be found in Th. Pigeaud, Java in the Fourteenth Century (The Hague: Martinus Nijhoff, 1963), III: see, respective1y, the Sarwadharma Charter (pp. 143-150), the Charters of Shela Mandi (pp. 175-177), the Charter of Katiden (p. 174), the Chàrters of Biluluk (pp. 166-168) and the Decree Jaya Song (pp. 151155). A suddhapattra is discussed by J. G. de Casparis, Selected Inscriptions from the Seventh to the Ninth Century A.D. (Bandung: Dinas Purbakala Republik Indonesia, 1956), pp. 330-337. Because of the lack of self-identification, as well as the practical problems caused by the absence of a translation, a jayapattra transcribed by stutterheim has not been included in this study. The jayapattra is contained in, W. F. Stutterheim, "Transcriptie van Twee Jayapattra's," in Oudheidkundige Dienst van Nederlandsch-Indië, Oudheidkundig Verslag 1925 (Weltevreden: Albrecht, 1926), pp. 57-59.

2. F. H. van Naerssen, "Oudjavaansch Oorkonden in Duitsche en Deensche Verzamelingen " (Unpub1ished thesis, Leiden University, 1941), p. 32 , note 2 . 
came into being. Accordingly, it furnishes an exceedingly rich store of data on the functioning of Javanese judicial and administrative institutions.

The potential contribution of the jayapattra to the study of Javanese history has long been recognized. As early as 1889, J. L. A. Brandes, in his pioneering, article, "Een Jayapattra of Acte van een Rechterlijke Uitspraak van Saka $849, " 3$ drew upon data contained in the Guntur jayapattra in his discussion and summary of the current state of knowledge concerning the problem of the Hinduization of Java. Nearly half a century later, in "Epigraphia," ${ }^{4} \mathrm{~W}$. F. Stutterheim used the contents of the other tenth century jayapattra, the Wurudu Kidul inscription of $922 \mathrm{~A} . \mathrm{D}$., to discuss problems of class in old Java. More recently, the two Madjapahit examples of the genre, the Bendosari plates and the Parung fragment, published respecively in Pigeaud's monumental Java in the Fourteenth Centurys and Cohen Stuart's Kawi Oorkonden, ${ }^{6}$ were utilized by the former to analyze the important issue of landed estates and land-ownership in Singasari-Madjapahit Java. Finally, G. A. J. Hazeu also made use of information contained in modern Javanese jayapattra in his consideration of the legal procedures of eighteenth-century Tjirebon. This study is found in his article "Tjeribonsch Wetboek (Pepakem Tjerbon) van het Jaar 1768."7

Not only are the jayapattra important sources for the political history of Java in various periods; they also represent a well established genre of Javanese legal document. They have, in fact, been employed as legal tools by the Javanese judiciary from at least as far back as the early tenth century up until the time of the Pepakem Tjerbon in the eighteenth. The striking persistence of the jayapattra throughout this span of time attests to its enduring importance within

3. J. Brandes, "Een Jayapattra of Acte van een Rechterlijke Uitspraak van Saka 849," Tijdschrift voor Indische Taal-, Land-en Volkenkunde, 32 (1889), pp, 89-150. The date of the inscription has since been corrected to Saka 829. R. Goris, "De Oud-Javaansche Inscripties uit het Sri-Wedari-Museum te Soerakarta," in Oudheidkundige Dienst van Nederlandsch-Indië, Oudheidkundig Verslag 1928 (Weltevreden: Albrecht, 1929), p. 64. According to L. C, Damais, "Etudes d'Épigraphie Indonesiénne," Bulletin de l'École Française d'Extrême Orient, 46 (1952), pp. 1-105, the corrected date should be A.D. July 7,907 .

4. W. F. Stutterheim, "Epigraphia," Tijdschrift voor Indische Taa1-, Land- en Volkenkunde, 75 (1935), pp. 444-456.

5. Pigeaud, Java in the Fourteenth Century, III, pp. 151-155. Pigeaud discusses the contents of the "Decree Jaya Song" jayapattra in ibid., IV, pp. 391-398.

6. A. B. Cohen Stuart, Kawi Oorkonden in Facsimile met Inleiding en Transcriptie (Leiden: E. J. Bril1, 1875), pp. 26-27.

7. G. A. J. Hazeu, "Tjeribonsch Wetboek (Pepakem Tjerbon) van het Jaar 1768," Verhandelingen van het Koninklijk Bataviaasch Genootschap van Kunsten en Wetenschappen, 55, No. 2 (1905), pp. 118 (esp.p. 17), and his notes to the text, pp. 132-135. 
the Javanese administrative tradition despite continuing political and social change. This study, therefore, will trace the historical development of the jayapattra from its origin in the Hindu legal system through its adoption by and employment in the Hindu-Javanese judiciary down to its survival as an integral part of the judicial system of Islamicized Tjirebon. In this way, it is hoped that the consistent characteristics of the genre and of the judicial administration which it served can be delineated.

The earliest reference to a jayapattra as a basic component of the ancient Indian judicial system is found in the Narada-smrti, ${ }^{8}$ written sometime during the first four centuries A.D. Describing the final stage of the judicial procedure, the author declares that:

One condemned by the judges shall be punished by the King according to $1 \mathrm{aw}$. The victorious party shall receive a document recording his victory [a jayapattra], [and] couched in appropriate language. ${ }^{9}$

Thus, from the start, a fundamental assumption underlying the issuance of a jayapattra is that the case must be of a civil nature, i.e., that it must involve two disputing parties, one of whom wins the case and is thereupon awarded a "victory certificate." By contrast, in the event of crimes against the ruler of the kingdom, a jayapattra would be considered unnecessary as the winning party would be the state itself. An example of the latter type of case can be found in the trial scene of the play The Little Clay Cart (Mrechakatika), ascribed to the third century playwright Südraka. ${ }^{10}$

Later smrti writers such as Brhaspati, Kātyāyana, VrddhuVasistha and Vyāsa elaborated further on the contents of a jayapattra. According to them, the document should include an accurate record of the plaint and the defense, the evidence considered at the trial, the law texts applicable to the case, as well as the decision, signed by the chief justice and stamped with the royal seal.11 Moreover, it is implicit in the smrti writings and is explicitly stated by later commentators ${ }^{2}$ that the jayapattra was issued in order to insure that the matter under consideration be settled for good and not become the object of renewed litigation. The jayapattra, as defined by the Hindu jurists, should provide, therefore, an invaluable source of

8. Pandurang Vaman Kane, History of the Dharmasastra (Poona: Bandarkar Orienta1 Research Institute, 1930-1962), III, pp. 380-381.

9. Julius Jolly, trans., The Minor Law-Books: Narada and Brihaspati (Oxford: Clarendon Press, 1889), p. 35 .

10. The scene occurs in Act IX. The play can be found in J. A. B. van Buitenen, trans., Two Plays of Ancient India (New York: Columbia University Press, 1968); see a1so, H. F. Ursekar, "The Court Scene in Mrcchakatika," in S. N. Gajendragadkar and S. A. Upadhyaya, eds., H. D. Velankar Commemorative Volume (Bombay: n.p., 1965), pp. 108-189.

11. Kane, History of the Dharmasastra, p. 380 .

12. Ibid., pp. 381-382. 
accurate, datable information concerning the workings of the ancient Indian courts of law.

Evidence that the jayapattra was indeed utilized by Hindu law courts in the intervening period between the smrti texts of the sixth and seventh centuries and the earliest epigraphic reference to a jayapattra in the early thirteenth century is provided by an examination of the legal systems in other parts of the Hindu world. For example, the extant epigraphy from the Hinduized areas of Southeast Asia demonstrates that, from at least the tenth century on Java and possibly earlier in Cambodia, jayapattra were regularly employed in local legal administration. ${ }^{3}$ Their utilization in actual 1 itigation on Java, attested to by the presence of jayapattra inscriptions, indicates a similar use in the land of its origin. The Javanese custom of occasionally having them inscribed on copper plates possibly accounts for their preservation in Java but not in India at this time.

Indian jayapattra are, in fact, represented by a relatively small number of geographically dispersed examples. Among them are the previously mentioned Karanese inscription of about $1200 \mathrm{~A} . \mathrm{D} . \mathrm{I}^{14}$ (referring to a jayapattra given to Ekantada-Rama, the medieval South Indian cultural hero, in recognition of his victory over a group of Jain priests), two South Indian jayapattra recording ordeals to settle land disputes in the Yádava and Vijayanagar kingdoms, dating from the thirteenth and seventeenth centuries respectively, ${ }^{15}$ and an eighteenth century Sanskrit jayapattra from Darbhanga, Bihar, relating the process of a trial over the legal ownership of a female slave. ${ }^{16}$ However, of the three extant Indian jayapattra, only the last conforms to the requirements set down by the smrti writers for the jayapattra format. In it, both plaint and defense are reported in considerable detail, the evidence and its evaluation according to the appropriate

13. The manufacture of Cambodian pattra, mentioned in 1 ine 17 of the Prasat Kravan inscription of $921 \mathrm{~A} . \mathrm{D}$., testifies that the pattra was in use in the country at that time and further suggests that the use of the jayapattra was also highly likely. George Coedès, ed. and trans., Inscriptions du Cambodge (Paris: E. de Baccard, 1937-1954), IV, p. 73.

14. "Inscription of Ablur," in Epigraphica Indica (Calcutta: Office of the Superintendent of Government Printing, 1898-1899), V, pp. $237-260$.

15. "Inscriptions in the Shimoga District, Sorab Taluq \#387," in B. Lewis Price, ed., Epigraphia Carnatica (Bangalore, Mysore: Government Centra1 Press, 1904), VIII, pp. 68-69; Mysore Archaeologica1 Department, Annual Report for 1918 (Bangalore, Mysore: Government Press, 1919), p. 54. A section of the latter inscription can be found in T. V. Mahalingan, Administration and Social Life under Vijayanagar (Madras: University of Madras, 1940), pp. 121-122.

16. K. P. Jayaswal, "A Judgment of a Hindu Court in Sanskrit," Journal of the Bihar Research Society, 6 (1920), pp. 246-258. A1so of considerable interest for the light it sheds on Hindu jurisprudence between the age of the smrti writers and the Islamic invasions is J. D. M. Derrett, "Law and Social Order before the Mohammedan Conquest," in Religion, Law and the State in India (London: Faber \& Faber, 1968), pp. 171-224. 
smrti text are stated in full, and the decision of the chief justice and his signature are recorded.

In contrast, both the form and the language of the remaining jayapattra set them apart from the Bihar document and the requirements of the smrti texts. The South Indian examples seem to have been primarily concerned with recording trials by ordeal instituted to settle legal disputes. For this reason, and because of their brevity, they provide little information on the actual workings of Hindu law courts during the period in which they were promulgated. Furthermore, like their Javanese counterparts, they tend to use the regional language of the area as the medium of expression, which further distinguishes them from the Sanskritic Bihar document and the smrti texts.

A similar reliance on either the regional language or on Persian (due to the influence of Mughul institutions in sixteenth and seventeenth century India), is a1so noticeable in the legal administration of both the Marathas and the Sikhs.17 This tendency to promulgate legal documents in the local tongue or in a special administrative language may be related to the divergence in form of these lega 1 documents from the smrti prescriptions, although this question still awaits detailed study: Whatever the relationship between the language and the form of administrative records, there seems to have existed considerable variety in the manner in which legal systems manifested themselves throughout the Indic world. However, the existence of such variations within Hindu administrative systems as well as the presence of discrepancies between Sanskritic models and actual legal practice in certain areas does not detract from the fact that, at the same time, there existed a reasonably orthodox expression of the smrti ideals, a representative of which is found in the Darbhanga jayapattra.

At present, it has not been established when and how Indian legal concepts and instruments, including the use of the jayapattra, first began to influence Javanese institutions. Certainly, by the eighth century, Hindu ideals of jurisprudence were not unknown on Java. King Sanjaya's comparison of his father with Manu in the Tjanggal inscription of $732 \mathrm{~A} . \mathrm{D}$. testifies to the Indian lawgiver's reputation among the ruling elite of old Java. ${ }^{18}$ Another eighth century inscription, a suddhapattra of 794 A.D., demonstrates that Sanskrit pattra (certificates) were being used in legal transactions by the Javanese, indicating not only an awareness of Hindu concepts but also a willingness to utilize them in local administrative operations. ${ }^{19}$ These examples represent no more than the surface traces of the process of incorporating Indic elements into o1d

17. Vithal Trimbak Gune, The Judicial System of the Marathas (Poona: Deccan College Post-Graduate Research Institute, 1953), pp. 79 and 135; U. C. Sarkar, Epochs in Hindu Lega1 History (Hoshiarpur: Vishveshvaranard Vedic Research Institute, 1958), pp. 268-269.

18. Hendrik Kern, Verspreide Geschriften ('s-Gravenhage: Martinus Nijhoff, 1913-1928), VII, p. 120, line 8; Sañjaya Inscription of October 6,732 in Damais, "Etudes," p. 20.

19. de Casparis, Selected Inscriptions, pp. 335-337. 
Javanese society, and hence their presence should caution one against overemphasizing the appearance of the fully developed jayapattra, seemingly without precedent, in the early tenth century.

Central Javanese jayapattra of this era are represented by two examples of unknown origin dated 922 and 907 A.D.20 Both documents record the results of civil suits. The 922 Guntur inscription relates the proceedings of a suit to recover a debt from a borrower's husband, since the original debtor had died in the interim. The other case, described in the Wurudu Kidul plates, concerns a dispute over the class standing of the defendant, a certain Dhanadi, who, after winning the case, paid to have the entire jayapattra engraved on copper.21 Both documents state clearly that they were issued so that ". . . the case[s] would never again be spoken about." ${ }^{2}$ Also, as is to be expected from this genre, the pattra record the plaint and defense, the type of evidence used in the trial, as we 11 as the decision of the judges.

Although the Javanese documents clearly follow the Hindu model in the main, certain clear divergences must be noted. The most noticeable of these are the substitution of old Javanese for Sanskrit as the medium of expression, and the failure to cite the relevant smrti texts, even when the cases involve a ruling by the presiding judge. For example, in the previously mentioned Tabwel vs. Dharma case of 922 , the judge dismissed the suit on the grounds of the plaintiff's non-appearance at court, as well as on the basis of a technical ruling that a debt contracted by a woman was not her husband's legal responsibility ". . . if he had no foreknowledge of the transaction and if there had been no children born of that marriage."23

20. The Wurudu Kidul plates (A and B), contained in Stutterheim, "Epigraphia"; Damais, "Etudes," inscriptions \#100 and 101; and the Guntur plate in Brandes, "Een Jayapattra."

21. The Wurudu Kidul plates in Stutterheim, "Epigraphia"; the text is on p. 452 and the Dutch translation on p. 455 , see also the footnote on p. 455. The action by the winner of engraving the jayapattra on copper may have been common practice in o1d Java, and, if so, it would explain the survival of more Javanese jayapattra as compared to Indian ones.

22. Wuruḍu Kidu1: "Nāhan sira mawai(h) jayapattra. yathanya tan hanāwuwusa ring dlāh ning dlāha āpan huwus mabungah kawiwekãnya." Contained in Ibid., p. 451; the Dutch translation is on p. 453; the Guntur plate reads: "Kunang sugyan ta tan pagujara ya muwah d1ah ning dlah ya donikeng jayapattra." Contained in Brandes, "Een Jayapattra," pp. 147-148.

23. Guntur plate: "Ya tan ganawruh nikang lakilaki, nguniweh yan tan hana anak sambandha." Contained in Brandes, "Een Jayapattra," pp. 146-147. The ruling implies the existence of a highly-developed body of legal theory. Unfortunately, however, the document itself does not contain any specific information about the status, type or use of law texts during this period. The Wurudu Kidul plate likewise contains no information on this subjèct. 
More important than the divergence in form between the Javanese and Indian jayapattra is the fundamental dissimilarity they reveal in the manner of conducting trials and in reaching final verdicts in the two areas. In India, the conduct of a trial was entirely in the hands of a chief justice, prädvivakka, with the other justices acting more as witnesses to the course of the trial than as participants in either the proceedings or the decision. The litigants addressed their pleas to the chief justice. In addition to deciding on the admissibility of certain types of evidence, he also cited the appropriate' smrti text to confirm his ruling. The chief justice also made the final judgment and signed the jayapattra. The lower judges are mentioned as signing the document only to show their concurrence with the decision of the prạdvivāka. ${ }^{24}$

In contrast to Indian procedure, the Javanese trial described in the Wurudu Kidul inscription was presided over by a samget, a notable or judge (in the sense of an arbitrator), who worked in concert with a council of elders. ${ }^{25}$ The proceedings, the interrogation of witnesses, and the issuance of the jayapattra to the winner were all done jointly by the samget and the council of elders. Furthermore, only the witnesses to the trial signed the document, not the judges. The silence in the record concerning who delivered the verdict, the joint responsibility of samget and council for all other parts of the trial, and the conspicuous omission of the signatures of samget and council on the document, all strongly suggest a collective decision-making process by the tribunal. The Tabwel vs. Dharma case is ambiguous on this matter since the trial never took place, leaving no opportunity for a decision by either a chief justice or a council of elders.

These significant differences between the Indian and Javanese jayapattra in regard to both form and content demonstrate that Javanese borrowing of Hindu legal tools involved neither a wholesale adoption of the Indian legal system nor an indiscriminate acceptance of its instruments. Not only did Javanese replace Sanskrit as the language of the court, but procedures were based on custom or local laws rather than upon smrti texts. Furthermore, the marked contrast between the institutiona1 arrangements of 1 aw courts in India and Java undoubtedly reflects a divergence in conceptions of judicial administration.

Deviations from the "standard" jayapattra model of the Hindu judicial tradition, while already present in the earliest Javanese examples, became even more pronounced in the fourteenth century. The clearest evidence that this was a quite self-conscious development lies in the fact that the documents are now styled jayasong rather than jayapattra. Pigeaud has pointed out that the first part of the new term, jaya, probably signifies an abbreviation of jayapattra, while song means a sunshade. ${ }^{26}$ Thus, the full meaning

24. Jayaswal, "Judgment of a Hindu Court," pp. 253-255.

25. See the full text in Stutterheim, "Epigraphia," p. 452. For a discussion of the samget/pameget as judges in o1d Java, see F. H. van Naerssen, "De Saptopapatti: Naar Aanleiding van een Tekstverbetering in den Nagarakrtagama," Bijdragen tot de Taa1 -, Land - en Volkenkunde, 90 (1933), pp. 239-258, esp. pp. 241-244 and 257-258.

26. Pigeaud, Java in the Fourteenth Century, IV, p. 391. 
of the term could be interpreted as "a jayapattra that protects the winner from further litigation as a sunshade protects one from the sun." The change in the name of these documents reflects a subtle shift in the reasons for their promulgation. The early jayapattra, following their Indian models, were intended primarily to insure that renewed litigation would not occur. The fourteenth century jayapattra, however, were more specific; they not only stated that the dispute was settled, but also that the winner ". . . secures over and over again the firmness of the protection of the headmen, the right honorable gentlemen [of the council]."27

Among the more significant changes that took place in the jayapattra format between the tenth and fourteenth centuries was the development of a style, typical of the later documents, which narrated events as they had occurred rather than merely summing up the main issues at stake, as had earlier been the rule. The events depicted in the Bendosari jayapattra proceed in a logical, narrative sequence from the opening of the trial ${ }^{28}$ through the hearing and evaluation of evidence ${ }^{2} g$ and the handing down of the verdict to the final issuing of the jayapattra. ${ }^{30}$ There seems to be none of the compression of time, the mere listing of events or the omission of unimportant details that are characteristic of the Guntur and Wurudu Kidul inscriptions. Finally, the use of verbs of action, as opposed to those of description, in referring to the participants' role in the court ${ }^{3}$ is suggestive of an attempt to narrate the events as they happened, rather than to note simply their occurrence.

Another innovation consisted in the rearranging of the different parts of the document. In contrast to the more Indic jayapattra which mention the plaint, then state the defense, and eventually record the verdict and the signatures of the witnesses, the Bendosari jayapattra begins with a long prologue listing the highest personages in the realm, starting with the king and queen and the "great ministers three," and only then introduces the people actually connected with the trial, i.e., the administrative council and the upapatti or assessors-at-1aw. Only when the preliminaries are disposed of does the jayapattra report the trial proper, listing in direct quotation the pleas of the litigants, beginning with the defendant and eventual winner. ${ }^{32}$

27. "Decree Jaya Song," 6, verso, 2 in Ibid., III; and Parung fragment, $1 \mathrm{~b}, 3$ and 4 in Cohen Stuart, Kawi Oorkonden.

28. "Decree Jaya Song," 4, recto, 2 and 3, in Pigeaud, Java in the Fourteenth Century, III.

29. Ibid., 4, verso, 2 to 6 , recto, 3 .

30. Ibid., 6 verso, 2 and 3 .

31. For example, in the "Decree Jaya Song," the litigants "were humbly begging," 4, recto, 4. The pleas of both claimants started with, "I am the owner of that 1 and," 4 , verso, 2 , and 5 , verso, 3 . The upapatti "sought the opinion of the lawbooks," 5, verso, 5. The council "then sent messengers," 6 , recto, 2 . Ibid.

32. "Decree Jaya Song," prologue, 2 , recto, 1 to 2 , verso, 2 ; judicial personnel, 2 , verso, 2 to 4 , recto, 4; and the pleas of the litigants, 
The present state of knowledge concerning Javanese legal history makes it difficult to account for the marked alteration in style and organization of this jayapattra. On the one hand, the use of long direct quotations in a narrative style and the omission of any mention of the trial's final outcome until the verdict is announced gives drama to an otherwise prosaic legal document. On the other hand, this literary style introduces a note of artificiality and an abundance of unnecessary details, irrelevant, that is, from a strictly legal point of view. Not only is the new order of the pleas illogical, because the defendant cannot make a meaningful defense before there is a plaint, but, in addition, much of it is not entirely necessary for the prosecution of the case. In fact, the defendant's testimony in attempting to establish ownership of the disputed land is irrelevant to the trial because the verdict was reached primarily on the grounds of the impossibility of proving the plaintiff's claims, not on the basis of the defense plea. ${ }^{3} 3$

The extended prologue, consuming nearly one half of the inscription, the sense of the dramatic, and the artificial presentation of the litigants' pleas suggest that the jayapattra may have come under the influence of literary conventions in inscription writing which stressed style at least as much as content. The Nagarakrtägama refers to such literary criteria in the composition of prasasti. ${ }^{34}$ Very likely this in turn had an effect on the writing style of all Madjapahit inscriptions. Though this literary influence may explain the innovations found in the Madjapahit jayapattra, there is no reason to assume that it adversely affected their reliability as records of actual legal cases. ${ }^{35}$

For despite stylistic changes, the judicial process recorded in the fourteenth century jayapattra is strikingly similar to that of the tenth century. Although the composition of the judicial officers and the manner of handling the cases show an increased specialization of function and a new sophistication, the basic structure of the early Mataram judiciary is completely recognizable in Madjapahit legal administration. The older pattern of an executive officer (samget) acting in concert with a council of village elders to dispense justice seems now to have been replaced by an executive council composed of the highest functionaries of the realm assisted by a college of legal specialists (upapatti), usually seven in number. ${ }^{36}$

Just as the samget had been in charge of bringing the Dhanadi case, described in the Wurudu Kidul inscription, before the judicial

4 , recto, 2 to 5 , verso, 5. Ibid. This part of the trial is missing from the Parung fragment.

33. Ibid., 6, recto, 5 .

34. Nāgarakrtāgama, $93-2-3$ and 4 .

35. Madjapahit literary influence on epigraphic records, generally, seems to have been confined to alterations in the style of the documents. There is no evidence that the content of inscriptions was willfully altered.

36. van Naerssen, "De Saptopapatti," pp. 239-259. 
tribuna1, so now the council in Madjapahit conducted the executive functions of the court, drawing upon the upapatti for specialized knowledge and assistance in its final judgement. Specifically, it was the council that was petitioned by the litigants to register their separate pleas. The council not only sent out the messengers to collect evidence but also confirmed its protection of the winner of the suit. On the other hand, the upapatti are specifically mentioned as consulting the lawbooks, chiefly the Kutāara Mãnawa, as well as ". . the opinion of the country, analogues, masters of yore, etc." ${ }^{3}$ In addition, they participated with the council in reaching a verdict. Thus, it seems that the duties of the samget and council of elders, acting together in every phase of the tenth century proceedings, were replaced four centuries later by an executive council and a college of legal specialists, each with its own specialized role to.play. The functions of the two groups dovetailed to develop a judgment on the case.

An examination of the manner in which the court arrived at a verdict also indicates that the Madjapahit legal system was a continuation of a typically Javanese line of development. The jayapattra of the period, in conformity with the trend initiated in their ancestors of the tenth century, were not signed by the participating jurists. Since the signing of a document was done to show concurrence with a verdict, the very act implies that there could be, and undoubted$1 y$ on occasion was, disagreement with a verdict, in which case an individual jurist might not sign the particular jayapattra. Under these conditions, the apparent unanimity of the decisions in Javanese law courts, attested to by the lack of a need to show concurrence by signing the document, strongly suggests that justice was dispensed by the Madjapahit courts in the same manner as by their tenth century predecessors, $i . e .$, through decisions collectively satisfactory to al1 jurists participating in the trial. That this method of making decisions, called musawarat-mupakat or "mutual discussion-collective decision" in modern Javanese, ${ }^{3}$ is one of the most important techniques of handling administrative affairs in modern Javanese rural society (especially in councils at the village leve1) increases the plausibility of this contention. ${ }^{39}$

That the change in style but continuity in content represented by the Madjapahit jayapattra were lasting contributions to the development of Javanese legal practice rather than temporary aberrations or expressions of purely local traditions is attested to by the

37. "Decree Jaya Song," 5, verso, 5 to 6 , recto, 2 , in Pigeaud, Java in the Fourteenth Century, III; Parung fragment 1a, 2-4 in Cohen Stuart, Kawi Oorkonden.

38. Th. Pigeaud, Javaans-Nederlands Handwoordenboek (Groningen: J. B .

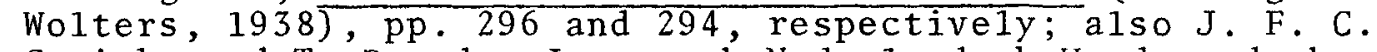
Gericke and T. Roorda, Javaansch-Neder landsch Handwoordenboek (Leiden: E. J. Bril1, 1901), II, pp. 501 and 511 .

39. Koentjaraningrat, "Tjelapar: A Village in South Central Java," in Koentjaraningrat, ed., Villages in Indonesia (Ithaca: Cornell University Press, 1967), pp. 244-280, esp. p. 274; also Koentjaraningrat, "The Village in Indonesia," in Ibid., pp. 386406 , esp. pp. 397-398 and 401. 
eighteenth century jayapattra of $\mathrm{T} j \mathrm{irebon}$. These documents are described by the Pepakem Tjerbon of the mid-eighteenth century, which states that the winner of a lawsuit shall be awarded a surat kukudung. A surat is a written certificate or document equivalent to the Sanskrit pattra, in this case a victorious pattra or jayapattra. Kukudung means a veil or sunshade. ${ }^{40}$ The surat kukudung was, thus, the modern Javanese equivalent of the fourteenth century jayasong, and undoubtedly carried the same meaning--a letter protecting one against further litigation like a sunshade protecting one from the heat of the sun.

The only surat kukudung type of document that seems to have survived from the eighteenth century was published by F. K. Holle, in 1869 , as a Dutch translation of a Javanese court record. ${ }^{41}$ This acte reported the outcome of a land dispute settled by the Tjirebon tumenggung court, which was composed of the four tumenggung and the Dutch resident. Ostensibly, the dispute could not be resolved in the lower djaksa court due to lack of conclusive evidence; hence resort was made to a higher court which employed ordeals and oaths to settle particularly difficult cases. ${ }^{42}$ The specific reference to the current Verenigde oostindische Compagnie resident, van Soesdijk, as sitting on the tumenggung court means that the acte must date from his tenure as resident in $\mathrm{Tj}$ irebon between 1734 and $1739 .^{43}$ Moreover, the close conformity of the document's description of court procedure to the contents of the Pepakem Tjerbon, a compilation from earlier lawbooks of laws current in Tjirebon, provides a clear illustration of how the general legal provisions in the Pepakem were utilized in actual legal practice in one part of Java during the eighteenth century.

A comparison of the acte with its predecessors of the tenth and fourteenth centuries reveals that the Tjirebon document adopted some of the Madjapahit innovations in the jayapattra form, while at the same time preserving the basic features of Javanese jurisprudence. For example, the use of a narrative style with direct quotations from the litigants' pleas and the placing of the eventual winner's plea first were maintained in the acte. On the other hand, the long

40. Pigeaud, Handwoordenboek, p. 208; also Gericke and Roorda, Handwoordenboek, I, sub-entries pikudung and lajang pikudung under the main entry for kudung.

41. F. K. Holle, "Bijdragen tot de Geschiedenis ter Preanger Regentschappen," Tijdschrift voor Indische Taal-, Land-en Volkenkunde, $17(1869), \mathrm{pp} \cdot 363-365$.

42. Ibid; also Hazeu, "Tjeribonsch Wetboek," p. 18 for the appeal of cases to the tumenggung court, and $p .43$ for regulations governing the water ordeal.

43. Fonger de Haan, Priangan (Batavia: G. Kolff, 1910-1912), IV, para. 2413. An earlier Dutch reference to a Tjirebon surat kukudung is contained in Jongbloet's memorandum of 1714 , in which he mentions the certificate of victory given to the winner in a Iawsuit as being a sourat coedong. De Haan gives a slightly different etymology for sourat coedong in his comments. Ibid., para 2364 . 
prologue, peculiar to the Madjapahit jayapattra, was omitted by the Tjirebon jurists, probably because it was considered to be a dispensable stylistic device. More importantly, the basic framework of Javanese legal administration was preserved, as the record of the $\mathrm{T} j$ irebon courts reveals. Both at the special appellate level reported by the acte and at the lower djaksa level, as will be shown subsequently, the legal administration was performed by a judicial tribunal in which no one member was superior to his colleagues. Hence, the form of the Tjirebon surat kukudung, represented by the acte of the early eighteenth century, attest $\dot{s}$ to the persistence of the jayapattra tradition well beyond the Hindu-Javanese era in which it had originated.

Additional testimony to the surat kukudung's position within the Javanese jayapattra tradition comes from the fact that the Tjirebon jurists did not adopt the Islamic form of document used in dealing with similar matters. For example, the sijill, ${ }^{44}$ written judgements of $k \bar{a} d i$ courts containing the same general information on the disposition of cases as the Sanskrit jayapattra, as we 11 as the muhzur ${ }^{45}$ (court minutes), were in widespread use at this time throughout the Islamic world, including parts of the Indonesian archipelago." 6 The Fatawa-i-Alamgiri, a Persian lawbook associated with the last of the Great Mughuls of India, Aurangzeb (d. 1707), defines the instruments as follows:

The muhzur contains a statement of the claim, the denial and the depositions of the witnesses. The sijill contains a repetition verbatim of the muhzur, and also the words of the witnesses, after which there is a record of the subsequent proceedings up to the final decree. ${ }^{47}$

But while the general content of the sijill was almost identical with that of the jayapattra, these documents were the end product of very different legal procedures. The sijill stemmed from courts of kạdi who attempted to apply the Shari'a (Islamic Law) to cases of actual litigation, ${ }^{48}$ whereas the surat kukudung, in contrast, were issued by

44. Joseph Schacht, An Introduction to Islamic Law (Oxford: Clarendon Press, 1964), pp. 83 and 189 .

45. For a discussion of the sijill and muhzur in comparison with the jayapattra, see Gune, Judicial System of the Marathas, pp. 71-81; Sarkar, Epochs in Hindu Legal History, p. 274. On the use of the sijill in the Indonesian archipelago, see R. J. Wilkinson, A Malay-English Dictionary (Mytilene: Salavopoulos \& Kinderlis, 1932), entry under sijil1.

46. The term sijill was used by Nurud-din Ar-Raniri in his Bustan a1Salatin, $i, 64$, written at the court of Iskandar II in Atjeh in the early seventeenth century. Cited by Wilkinson, MalayEnglish Dictionary, entry under sijill.

47. Fatawa-i-Alamgiri, IV, p. 247 as cited in Neil B. E. Baille, A Digest of Moohummudan Law (London: Smith, Elder \& Co., 1865), p. 753.

48. Th. W. Juynbol1, "Kạdi," in H. A. R. Gibb and J. H. Kramers, eds., Shorter Encyclopedia of Islam (Leiden: E. J. Bril1, 1953); Th. W. 
a tribunal of jurors who followed Javanese 1 aw and customs.

Tjirebon's loyalty to the jayapattra tradition in spite of the presence of other alternatives more closely related to the Islamic world clearly shows that her jurists looked to Java's glorious past for their models of jurisprudence rather than to the international world of Islam. This does not mean that Tjirebon was in reality unconverted and that her reputation as one of the important centers of the Islamic faith on Java was a sham. It merely indicates that Tjirebon, like many other states, was relatively slow to adopt new and foreign concepts and felt reluctant to abandon traditional customs and institutions. The choice between sijill and jayapattra should be seen as representing a choice between new and old institutions which also happened to be part of the distinctive Islamic and Hindu-Javanese administrative systems, not as a choice between Islam and Hinduism.

The retention of the Javanized jayapattra format by the Tjirebon jurists is paralleled by a clear continuity in juridical institutions, a record of which may have been kept in the surat kukudung in the same manner that earlier jayapattra recorded the workings of the judicial machinery of their own era. Fortunately the Pepakem discusses this matter in considerable detail. According to this text, the most important section of the judiciary was composed of a tribunal of seven djaksa, or justices, each of whom represented a geographic sector of the principality of Tjirebon. ${ }^{49}$ The number of djaksa seems to have remained constant despite the vicissitudes in political and geographic power of the principality. Thus, there were always seven djaksa whether Tjirebon was united under one ruler, as in 1680 , or divided under four, as in $1768 ;^{50}$ only the number of djaksa representing each sector varied. It seems clear that the seven-member tribunal was modelled on the Madjapahit college of upapatti, also ideally composed of seven members. ${ }^{1}$ Both colleges were composed of jurists learned in the legal knowledge considered appropriate to their respective societies, the upapatti in the Kutāra Mānawa and 01d Javanese custom, the djaksa in the lawbooks used in compiling the Pepakem Tjerbon.

The absence of an executive council, or official, with which the djaksa had to share responsibility marks the Tjirebon court off from its predecessors. The djaksa court was, at least until 1728 , the sole tribunal for civil cases in Tjirebon. ${ }^{2}$ Beneath this superficial organizational change, from a shared executive judicial to a purely judicial responsibility, the Javanese principle of unanimity in decision-making, particularly characteristic of legal administration, was preserved in the $\mathrm{T} j$ irebon djaksa court. The Pepakem states specifically that the judgment was to be one ". . in which all seven djaksa must agree, and the sentence is to

Juynbol1, Handleiding tot de Kennis van de Mohammedaansche Wet (Leiden: $\mathrm{E}$.J. Bri11, 1930), pp. 312-318.

49. Hazeu, "Tjeribonsch Wetboek," pp. 119-122.

50. Ibid.

51. R. A. Kern, Javaansche Rechtsbedeeling: Een Bijdrage tot de Kennis der Geschiedenis van Java (Leiden: E. J. Bril1, 1926), pp. 113114; van Naerssen, "De Saptopapatti," pp. 239-259.

52. Hazeu, "Tjeribonsch Wetboek," pp. 119-122. 
be given in the name of the Seven Djaksa."53 Thus, despite structural modifications, the underlying principles of Tjirebon jurisprudence hark back to a tradition in Javanese legal administration which is at least eight centuries old.

Persistence of a certain type of document in legal administration, consistency in the composition of judicial bodies, and continuity in the decision-making process seem to characterize Javanese legal history as it is revealed by a survey of the extant jayapattra. The jayapattra itself, origina1ly borrowed from the legal administration of ancient India, was adopted for use in the we11-established Javanese system of 1 aw at a relatively early date. Once accepted. the document recorded the basic continuities as well as changes in legal administration that have occurred during the development of Javanese jurisprudence from the eighth to the eighteenth centuries. It is striking proof of the degree to which the jayapattra had become an integral part of the Javanese system of administration that, despite its obviously Hindu origin, it continued to be used, with slight modifications, into the Islamic era.

A similar continuity in the composition of judicial bodies can a1so be discerned. Thus, the number of presiding jurists and the similarities in their technical training strongly suggest that the college of upapatti and the djaksa court were equivalent institutions and that the latter probably developed from the former. Furthermore, the Javanese preference for councils, boards and colleges to handle administrative matters, almost to the exclusion of individual offices, makes the contention that the college of upapatti derived ultimately from the tenth century council of elders very probable despite the lack of conclusive documentary proof so far.

Finally, a typically Javanese trait in judicial administration seems to be decision-making by the collective, unanimous judgment by a tribunal of jurors. A council of elders, a college of upapatti, or a tribunal of djaksa acted in the place usually occupied by an individual judge in legal systems found elsewhere in South and Southeast Asia. ${ }^{4}$ These bodies seem to have reached mutually satisfactory and, by implication, mutually binding solutions to legal

53. Ibid., p. 16. A translation of the original Dutch Treaty of 1768, added by Hazeu as the probable Javanese version of the treaty, reads: ". . . djaksa sapipitu amutussen pabenipun. . . " (pp. vi-vii).

54. Muslim law courts, including those of India, were usually presided over either by a single kâdí or a secular judge, both of whom were often assisted by seviral clerks. Schacht, Introduction to Islamic Law, esp. chapter 25 on procedure, pp. 188 ff.; Juynboll, "Kạ̦i." Similarly, in ancient Cambodia and Thailand, the courts seem to have been characterized by a single presiding judge, either the king or his direct representative. Robert Lingat, "L'Influence Juridique de 1 'Inde au Champa en au Cambodge, d'Après 1'Épigraphie," Journal Asiatique, 237 , No. 2 (1949), pp. 273-290; on the king as judge, H. de Mestier du Bourg, "Le Procès dans 1'Ancient Droit Khmer," Journal Asiatique, 264, No. 1 (1968), pp. 37-54; on the Rama Khamheng 
problems by means of collective discussion and mutual decision. In such a situation the authority of a decision would stem from the collective power possessed by the body as a whole rather than from the individual authority of a single juror. This method would add weight to a given decision by making the members of the board collectively responsible for upholding the final verdict.

The question may a1so be raised as to whether or not the decision-making methods employed in the judicial system were also applied to other areas of Javanese public life. Although a complete answer to this question must await further study, there is reason to think that these methods were not unique to village councils or courts of 1 aw, but were also utilized in other sectors of Javanese government to render decisions more lasting and efficacious.

The Nägarakrtagama, for example, reports that during the Madjapahit dynastic council convened in 1364 A.D. to choose a successor for the deceased prime minister, the final decision was made on a fully collective basis involving every member of the royal assembly.5 Such a decision-making process meant that once the group had agreed to a measure, all its members then had a stake and were committed to it, thereby foregoing a unity of intent between the political leaders of the state. That the converse could also happen is illustrated by the case of Paku Buwana II of Mataram $(1725-1749)$. M. C. Ricklefs has recently pointed out ${ }^{6}$ that the Central Javanese rulers in the eighteenth century could not make binding agreements between themselves and outside powers (in this case the Verenigde Oostindische Compagnie) without the close cooperation and consent of the kingdom's powerful ministers, 1ocal lords and court officials. The Susuhunan's attempt to do so had disastrous consequences. Since the local potentates had had no part in the crucial decision as to whether or not to sign the agreement with the Dutch, they felt no ob1igation to respect its provisions. This attitude seriously undermined the Susuhunan's authority and ultimately contributed to the downfall of the kingdom.

and Lu T'ai of Thailand as judges, G. Coedès, The Making of Southeast Asia (Berkeley: University of CaliforniaPress, 1966), pp. 145 ff.

55. Nāgarakrtāgama, 71-2-3, 4; also Poerbatjaraka, "Aantekeningen op de Năgaraḳrtăgama," Bijdragen tot de Taal-, Land-en Volkenkunde, 80 (1924), pp. 219-286.

56. M. C. Ricklefs, "Review of S. Moertono, State and Statecraft in Old Java," Journal of Southeast Asian Studies, 1, No. 1 (1970), pp. 116-117. 
